\title{
THE IMPLEMENTATION OF FOREIGN LANGUAGE LEARNING POLICIES AT STATE ISLAMIC HIGHER EDUCATION
}

\author{
Dian \\ Universitas Islam Negeri (UIN) Sunan Gunung Djati Bandung \\ Jl. A.H Nasution No.105 Cibiru Bandung, Jawa Barat, Indonesia \\ Email: dian@uinsgd.ac.id
}

Received: 05, 2019. Accepted: 07, 2019. Published: 07, 2019.

\begin{abstract}
Taking a part in foreign language learning in Indonesia has been an effort for the Indonesian people to be able to absorb and keep up with the development of science and meet the demand of global challenge. This study aims to investigate the implementation of foreign language learning policy at one of the state Islamic higher education as well as the challenges it encounters. The method used is descriptive qualitative by using instruments of observation, interviews, and document analysis. The results of this study show that the university implements language learning through the semester credit system program in regular classes, through courses in the language centre, learning in the fields of Ma'had Lughawy and Ma'had Al-Jami'ah. Meanwhile, the problems faced in the implementation process are related to human resources, facilities, and learning methods used.
\end{abstract}

Keywords: Ma'had Al-Jami'ah, Ma'had Lughawy, Foreign Language Learning

\begin{abstract}
ABSTRAK
Penyelenggaraan pembelajaran bahasa Asing di Indonesia merupakan upaya bagi bangsa Indonesia untuk bisa menyerap dan mengikuti perkembangan ilmu pengetabuan dan menjawab tantangan global. Penelitian ini bertujuan untuk menginvestigasi penerapan kebijakan pembelajaran dan pembudayaan berbahasa asing di lingkungan kampus islam dan mengetahui permasalahan-permasalahan yang dihadapi. Metode yang digunakan adalah deskriptif-kualitatif dengan menggunakan instrumen observasi, wawancara, dan analisis dokumen. Hasil dari penelitian ini menunjukan bahwa pihak kampus mengimplementasikan pembelajaran bahasa melalui program Sistem Kredit Semester di kelas reguler, melalui kursus di pusat bahasa, pembelajaran di Ma'bad Lughany dan Ma'bad Al-Jami'ah. Sedangkan, permasalaban-permasalah yang dibadapi dalam proses pengimplementasian tersebut berkaitan dengan sumber daya manusia, sarana, dan metode pembelajaran yang digunakan.
\end{abstract}

Kata Kunci: Ma'had Al-Jami'ah, Ma'had Lughany, Pembelajaran Bahasa Asing

\section{INTRODUCTION}

Learning foreign languages in university has been a challenge and features several problems to solve in terms of method, technique learning material and the goals of foreign language learning itself. To solve this problem, language educators have proposed several efforts and tried to innovate to achieve efficient and effective learning process, understandable and less boring circumstance. This circumstance should be established in language learning and teaching to ensure that language learners achieve the goal or objectives of foreign language learning in a particular program. Without proper strategy and creative effort, foreign language learning program will be difficult to achieve the maximum result set forward by the institution.

Mastering an international language is something that needs to be developed at this time. With the enactment of Indonesia as a member of the AEC (ASEAN Economic Community), it is fitting for the generation of the nation to be more advanced in terms of science and technology supported by the mastery of good and correct language. English is an important international language that can connect people to the world in various aspects including 
aspects of education. In other words, English has long occupied Asia and other continents as a lingua franca to communicate for several purposes like government, business, culture and etc. This has been demonstrated by government regulations that make English subjects a compulsory subject for students to learn from elementary school to high school. Even at the higher education level, all study programs must provide English language courses for 1 or 2 semesters although the disciplines taken are not related to English. This shows how important the mastery of foreign languages, especially English as one of the introductions to the success of one's academic field and to support a career in the world of work (Sinaga, 2010).

Learning English in a university is a must for students since its mastery equips them to be able to master knowledge in their field and communicate in the global communication for knowledge exchange. It is easier for international students to search and select any university to learn for master and doctor with English as a medium of instruction. In Indonesia, some universities have also provided international class where English is used to deliver instruction both in class and outside class. In other words, English mastery is a tool to participate in the global context (Wardah, 2016). Global competition requires any participant to be able to communicate with the global language like English where the language of commerce and internet is delivered in English.

Besides English, Arabic is also important, especially in Islamic higher education. Since the original sources of Islamic teachings, namely the Qur'an, hadith and Islamic sciences are written in Arabic, it is very important for Muslims, especially the scientific community to learn and understand and master Arabic. Arabic mastery enables Muslim to study Islam from the original source that comes from Arabic. This language has something to do with Islam and the effort to learn the source of religion. This position has offered another value for Arabic to learn by Muslim in any country. Therefore learning Arabic in Islamic Education is very important both as a mean of communication and to strive forward in an effort to understand in depth Islam (Andriani, 2015).

In the modern day, studying Islam has been offered not only by specialists and scholars in the field. Islamic studies as a discipline have been a favourite course taken by many Muslims in Malaysia, at least, in the higher learning institutions. Many higher learning institutions have offered different courses in Islamic studies due to the overwhelming demands of the people since the year 2000. In all of the courses offered, the Arabic language has been made mandatory to all students who are taking the courses. It is widely believed that any students of Islamic studies must have some degree of command of the Arabic language. In other words, Arabic mastery will equip students and prepare them to deal with the challenge in understanding the topic written in books using Arabic.

Arabic learning is a challenge for students since they have not achieved the Arabic learning objectives. This problem happens because of several factors namely: 1) Teachers rely heavily on theory and knowledge of Arabic, not language skills; 2) learning material is not in line with the students' need both in spoken and written material; 3) learning process is teacher centered not student centered; 4) structure or grammar is delivered in a separate manner, less integrative, less meaningful, less attention to its social context; 5) assessment system emphasizes more on cognitive aspect and pay less attention for integrative language skills (Amirudin, 2017; Hidayat, 2012; Wahida, 2017). Those factors have to some extent contributed to the failure of students in mastering Arabic in four language skills and they have made it difficult for students to deal with Arabic text and expressing or communicating using Arabic.

Universitas Islam Negeri (UIN) Sunan Gunung Djati Bandung, one of the state Islamic higher education in Indonesia, has the vision to strive and achieve "Being a superior Islamic State University and competitive knowledge-based revelation to guide the moral frame karimah in ASEAN 2025". 
This vision is an effort to deal with the global challenge. There are various efforts that need to be taken to realize this university vision. The effort include management, curriculum, facilities, human resource development, network and other supporting factors like International language use.

To achieve the vision, UIN Sunan Gunung Djati Bandung has to take into consideration international language mastery for lecturers and students. Some strategies to ensure the achievement of this vision should be secured. There is a need to set the policy of international language program for students and lecturers. Policy implementation of English and Arabic learning needs to be prioritized. This policy is crucial to ensure students good command in performing International language to carry out communicating for the sake of knowledge seeking and publishing in the world of scholars.

To implement the policy and achieve the vision in UIN Sunan Gunung Djati Bandung, all the stake holders including lecturers face the huge challenge in many aspects. To realize the ideal language environment for students learning in the university is not an easy thing. In addition to having sufficient material understanding, a language lecturer should know the level of mastery of the language of each student. It can be achieved through diagnostic test for students in the beginning of their learning program. If all conditions, in this context students' mastery on international language, are generalized, it will be difficult for language learners to achieve their good command in both English and Arabic. Basically, every student has different characteristics including learning techniques and mastery level of subject matter as in the concept of multiple intelligence (Stanford, 2003).

To date, the studies investigating international or foreign language learning in the context of state Islamic higher education are under research. This issue has been much investigated in the context of universities under Ministry of Research and Technology and Higher Education. This issue should be taken into consideration to provide good concern on the development of Islamic higher education in Indonesia. This study is interested in examining "Implementation of international languages (English and Arabic) learning policy in state Islamic university". The aim of this study was to investigate the purpose of implementing an international language policy in higher education, the programs that are provided to achieve the goals, the obstacles to implementing international language policies in universities, and the results achieved from the implementation of international language policies in UIN Sunan Gunung Djati Bandung.

\section{METHOD}

The characteristics of this study rest on the Phenomenology paradigm. The phenomenological view seeks to understand the meaning of events and their relationships (patterns of relations) to something in certain situations. Phenomenological is basically very influenced by Edmund Husserl and Alfred Schultz. Other influences come from Max Weber who emphasized on the interpretative understanding of human understanding (verstehen.) (Moleong, 2004). Thus, the qualitative nature of this study lies in the approach, methodology, as well as on technical analysis. For the object-specifics, this study uses "logical-verbal qualitative analysis techniques through essential searches" (Moleong, 2004).

In line with the paradigm, the methodology used is a descriptive-qualitative method, which is trying to obtain a factual picture about the Implementation of International Language Culture Policy in Higher Education, Case Studies at UIN Sunan Gunung Djati Bandung. The use of qualitative approaches is carried out mainly to gain breadth in developing the right instrumentation and getting accurate information, from the limitations of the bulkhead that is the subject and object of this study. The strategic steps of carrying out the data collection are developed starting from the technical observations, transmissions, in-depth interviews and document analysis. 
The data collection was conducted by using three techniques namely: observation, interview and documentation. The observation process was conducted by three ways; Observation and background description analysis, observation and document analysis, and participatory observation.

Data that is successfully obtained through the various techniques mentioned above and preliminary analysis have been carried out shortly after the data collection process in the field, then arranged into a description format (reduction) and presented in the processing matrix (display) to help the analysis (verification). The next phase is to conduct units arrangement and categorization, validity examination and the last stage is data interpretation.

\section{RESULTS AND DISCUSSION}

\section{The Purpose of International Language Policy at UIN Sunan Gunung Djati Bandung}

This study investigates the implementation of international language policy in Islamic higher education. Islamic Higher Education is one of the highest levels of Islamic education. The existence of Islamic education in the national education arena in Indonesia has a huge urgency, especially as a pillar for building Islamic education as a whole. Islamic Higher Education has a mission as a center of excellence to produce a strategic market that is very effective and benefits from education for stakeholders. To realize this goal, Islamic universities formulate a planned, focused, and sustainable vision, mission, strategy and work program that is used by the academic community as a guideline to achieve goals.

Quality assurance in achieving goals, Islamic tertiary institutions need the carrying capacity of human resources (HR), namely leaders, lecturers, administrative staff, and quality and quality students. Quality human resources occupy important and strategic positions in the framework of the learning process in Islamic Higher Education. This is because the leaders, lecturers, and administrative staff are able to create conditions conducive to the process of service to customers. Improving the performance and quality of the entire academic community is not only through increasing sources of funds and human resources but through the paradigm that develops in institutions of Islamic higher education by building organizational culture through a value system. It goes without saying that institution in this case university has to deal with the empowerment of the human resource in terms of their capacity to achieve the mission of the university.

Based on the findings of the research both in the form of data and direct activities observed in the field from the three international language policy systems, namely semester credits system, Ma'had Al-Jami'ah and Ma'had Lughawy administered on campus. Based in the interview with the rector of UIN Bandung, (Mahmud, 2019) in March 3, 2019 and Chairperson of Language Center, (Kodir, 2019) in March 15, 2019 the goal of foreign language learning implementation in UIN Bandung is to provide and improve students' language skills and prepare prospective graduate who possesses good command of International languages. It seems that this policy needs to be implemented as one of the effort to achieve the vision and mission of the university. Without this policy, the university has no clear goal and proper framework to build student good competence in performing international language.

\section{Program for Implementing International Language Policies at UIN Sunan Gunung Djati}

The word implementation in public policy literature was recently used. Although the public policy has been going on for a very long time, modern literature that deals with it is very much. the term implementation is categorized new 'found'. Previously it was only referred to as "administrative process" or "law enforcement". Found or not, what is meant by 
the implementation of the policy has been going on for centuries which is described as an activity "interaction between determining objectives and actions taken to achieve these goals".

As a higher education institution UIN Sunan Gunung Djati Bandung is truly committed to efforts to educate the nation's life, this is done by trying to realize and implement a quality and professional education system. In connection with efforts to improve capabilities, proficiency and other language competencies, the Sunan Gunung Djati Bandung Islamic University organized three international language learning systems, two of which are ma'badbased institutions (pesantren) that specifically deepen international languages, especially Arabic and English. Besides, UIN Sunan Gunung Djati Bandung also facilitates students to have Language courses at Language Center (result of interview with the rector dated $05-2019)$ ). To be detailed, following are the program conducted to implement the international language policies:

1) Language Center

Language Center of UIN Sunan Gunung Djati Bandung is a supporting element of the university that is positioned as an institution that carries out various activities to improve the competence of language skills in order to develop academic activities and the quality of graduates who uphold professionalism. Language skills activities, especially Arabic and English for students are the prerequisites for the Munaqasah exam proven to have a TOAFL and TOEFL certificate with a predetermined score. Given this authority in mind, Language Centre has a key role in ensuring students' competence to perform international language. In addition language centre has been a determining unit that equip students to meet the demand of administrative for the sake of participating in the test before they accomplish their academic program (Academic Team UIN Bandung, 2015).

The Language Center of UIN Sunan Gunung Djati Bandung has a vision: "to become a reliable institution in the field of language and culture in order to educate and strengthen identity, character, and dignity of Sunan Gunung Djati UIN Bandung to strengthen world-class university competitiveness." Efforts to realize the institution require special academic activities, the Center for Language Development as a typical academic service in the field of linguistics contributes as a facilitator to improve Indonesian, Arabic and English language competence. Efforts to improve the performance of the Language Center require a strong carrying capacity. First, the internal performance of the Language Center institution is focused on the goals and based on the rationalization of the work program to achieve the goal. Second, synergy of the leadership policies of providing work facilities for the Language Center (HR and SDA) and policies that lead to international language culture for the academics of UIN Sunan Gunung Djati Bandung. Third, awareness and actualization of international language learning in UIN Sunan Gunung Djati Bandung as a tri dharma requirement for higher education. In the end, the implementation of the three prerequisites was measured in Indonesian, Arabic and English language cultural products in UIN Sunan Gunung Djati Bandung environment.

The challenge of UIN Sunan Gunung Djati Bandung in facing global competition is to put it in line with the leading universities in the world. In order to achieve this goal, international language culture (Arabic and English) is a key instrument for achieving UIN Sunan Gunung Djati Bandung as an international class university (world class university). It is realized that the Center for Language Development is one of the drivers of the realization of an international language culture and a global quality culture through a program organized by the Language Development Center, so the implementation of the language Center programs requires the support of various parties to realize together with UIN Sunan Gunung Djati Bandung world-class university. Without real and strong support from other stakeholders, it will be difficult for language centre to carry it its mission in facilitating and equipping students with international language skill mastery. 
Based on the interview with Abdul Kodir (February 8, 2019) language learning program in language center is divided into two: 1) TOEFA and TOAFL program and course program. For TOEFA and TOAFL, the program is scheduled three time in a week with learning duration of 2 credit hour (1,5 hours) for 12 meetings. On the other hand, course program which is divided into two categories namely language skills course and preparation for TOEFA and TOEFL. The preparation for English and Arabic is administered three times in a week and. TOEFA and TOEFL, the program is administered three times a week. Duration for learning is 2 credit hour (1,5 hours) for 12 meetings.

In a detailed description, students sitting in $6^{\text {th }}$ semester with 4.844 persons taking part for TOEFA and TOEFL test. On the other hand, students who enrolled for language learning course were 4.995 persons. They learn international language to achieve the objectives and master language skills. Their achievement will be recognized by certifying them for TOEFA and TOAFL. In terms of score to achieve in both test, students from any department should achieve 450 points both for TOEFA and TOAFL. The score to achieve is higher for students from English and Arabic department. They must achieve 475 for each test respectively. This make sense since students from respective foreign language department have ample opportunities to practice and learn their expertise in their department. It is different circumstance with other students from other department who have less and minimum exposure to international language circumstance.

To boost students' motivation to participate in International language learning, certificate of TOEFA and TOAFL are set to be requirement for students to be able to take the comprehensive test and thesis seminar. This period comes at the end of learning period for students in strata 1 . This complements the study program mastery not only in subject of their study program but also international language competency. In addition, the certificate serves as requirement for international scholarship application. University has signaled the importance of this certificate before they try to apply for international scholarship. These administrative benefit has set the students interest and motivation to learn international language in language Centre since it will contribute to their success academically in the future career.

2) Ma’had Al-Jami'ah

Ma'had Al-Jami'ah has a forum for fostering students in developing religious and linguistic sciences, as well as naming and preserving the tradition of religious spirituality, is an academic subsystem and fostering students in order to implement the vision and mission of Islamic Higher Education. This unit contributes to the nurturing of academic environment for students in the university. In addition to class environment, students have more environment for Islamic traditional book learning in this unit.

Historically, Ma'had Al-Jami'ah was an institutionalization of the pesantren tradition into the campus of the Islamic Higher Education (PTAI). Therefore, Ma'had Al-Jami'ah must reflect the values of Islam, transform science and experience of Islamic tradition, and become a model of Indonesian Islamic education because it emerges and develops and the sociological experience of its environmental community. This image can be pursued if students and university are able to realize the vision and mission of Ma'had Al-Jami'ah. It is on the part of students to seize the benefit and opportunity to learn more Islamic knowledge from this unit.

Islamic sciences which were taught in Ma'had Al-Jami'ah originated from classical intellectual treasures, encouraging intellectual attitudes that cling to rich Islamic traditions. Ma'had is a pride among other old buildings. According to (Mustafa, 2019), director of Ma'had Al-Jami'ah, the change in the name Ma'had Al-Jami'ah became Ma'had Al-Jami'ah because of adopting it from UIN Malang which had been successful and received a good response from 
the Ministry of Religion. For this reason, all UINs use the name Ma'had Al-Jami'ah. That is the story behind the naming of Ma'had Al-Jami'ah.

Learning Arabic and English is the main menu in the santri ma'had curriculum, which is two times a week. In addition, learning kitab kuning is carried out once a week to print Islamic mahad santri. Teachers who teach are taken directly from language centers that are capable and competent in their fields. Besides learning Arabic, English and kitab kuning / Islamic traditional books, they are also taught public speaking and show their talents and expertise in their respective fields in one event every week (Badruzzaman, 2019). This ensure students learning process to achieve the goal of being competent and capable in reading and understanding the Arabic text book.

Ma'had Al-Jami'ah is intended by new student candidates at UIN Sunan Gunung Djati every year. They undergo learning before being declared graduated a year later. Every year, Ma'had is ready to accommodate around 120 prospective students. Before being accommodated as ma'had resident, prospective students must go through several stages such as interview selection, ability, filling out forms, and written language tests. If they pass, they will be accepted as Ma'had Aljami'ah students. If they fail, they do not have the chance to be accepted as a resident in this international language learning unit.

In the ma'had environment, students are only allowed to use two languages, namely Arabic and English. The goal, so that the santri are accustomed to using both languages in daily activities. Proper and ample opportunities to practice international language will nurture student practice and perform their international language for the purposes of communication. In contrast, without ample opportunities to practice, students will have fewer practice and will not contribute to their foreign language mastery.

3) Ma'had Lughawy

$\mathrm{Al}$ Ma'had Lughawy is an excellent program featured by Arabic education department from Tarbiyah Faculty. This institution was established since 2008 on the cooperation between Arabic education department and Amal Bakti foundation. Its aim is to prepare students to master language skills that is listening, speaking, reading and writing. Considering the importance of this language encouragement, Arabic education department freshmen must participate in this language learning unit (Wahyudin, 2019).

In Ma'had Lughawy, the curriculum consists of four aspects namely; linguistic study, Islamic study, tabfidz quran and self-development-related program. Through various activities and program, students are given ample opportunities to develop their language skills and talents. Having gone through several programs, some students have achieved in several competitions for language and art championship in, regional, national, Asia and even International level (Saepurrohman, 2019). It goes without saying that this foreign language learning unit has contributed hugely to students' competencies in Arabic.

In Ma'had Lughawy, all learning process are guided by lecturers from Arabic education department and high achievers from senior students. In other words, best instructors have been designed to ensure the good quality of international language learning delivery. As a medium instruction, Indonesia and Arabic language are used to deliver material. This happens to facilitate students understanding in trying to read and deal with Arabic traditional book delivered in the class. The institution has a paramount position to contribute to students' mastery in Arabic four language skills and their Islamic knowledge.

Saepurrohman (2019) describe the objectives of Ma'had Lughawy which fall specifically to:

a. Improve four language skills, namely listening (maharatul istima'), speaking (maharatul kalam), reading (mabaratul qira'ab), and writing (mabaratul kitabah). The ability of students to speak Arabic (maharatul kalam). 
b. Improve the ability of students to master Arabic grammar (qawa'idul lughah) and be able to apply it.

c. Improve the ability of students to translate, both from Arabic to Indonesian or vice versa

d. Improve student understanding on Islamic studies.

The objectives described above have to some extent guaranteed students participating in this international language learning unit to strive and be competent in several skills they need to deal with university tasks or assignment and for future need in their society.

\section{The Policy Making Process of UIN Sunan Gunung Djati Bandung}

Educational policy (Riant, 2008) is defined as a collection of laws or rules that govern the implementation of the education system, which includes the objectives of education and how to achieve these goals. As stated by Olsen and Codd (Riant, 2008) education policy is the key to excellence, even the existence of countries in global competition, so education policies need to be given top priority in the era of globalization. In other words, education policy is designed to provide legal basis for a particular program to be run in any particular education institution.

Thus it can be concluded that the foundation of educational policy is a legal concept that underlies the stipulation of a rule in the field of education in order to create harmony between needs and situations and conditions in the education process. According to Fredrickson and Hart the policy is: "an action that leads to a goal proposed by a person, group or government in a particular environment in connection with the existence of certain obstacles while looking for opportunities to achieve goals / realize desired goals (Tangkilisan, 2003). It can be understood that a particular educational policy is designed to achieve a particular goal in a particular educational institution.

As one of the higher education institutions, UIN Sunan Gunung Djati Bandung has the responsibility of fostering and preparing good, competent and superior graduates of the nation's next generation. Mastery of international language is crucial for the university to be able to participate in the global competition. Therefore various policies ranging from big things to small things must be well-behaved in order to be able to be administered and achieve its institutional goals. The goal set in the vision of the university requires proper and good strategy in terms of policy, its implementation and strategy to achieve its implementation.

\section{Challenges in Implementing International Language Policies at UIN Sunan Gunung Djati Bandung}

Implementation is not a simple process, but it is very complex and complicated and is a dynamic process, the end result of which cannot be estimated only from the availability of complete programs. Implementation functions to establish a link that allows policy objectives to materialize, so that it becomes what is called the results of work or government achievements. But in practice there is often a failure in implementation because even though it has been calculated in such a way, it does not mean the difficulties in the implementation process are gone. In management, every difficulty should be managed and sought its solution in order to achieve the goal of a particular organization.

A policy that has been rolled out is then realized in various programs and activities, certainly not always going well and smoothly means that it is a natural thing to meet with obstacles or problems. In this case, two factors, namely supporting and inhibiting factor, will certainly always exist side by side. Supporting factors are all aspects that can support both policies and programs. While inhibitors are all problems that become obstacles to policies and programs. After analyzing the challenges faced in implementing the foreign language learning policy, this study found three major challenges: 


\section{Human Resources}

\section{Students}

According to (Kodir, 2019) International language communication has not been implemented in UIN Sunan Gunung Djati Bandung for several reasons and one of them is low competence in language skills for English and Arabic among students. This is due to the fact that enrollment to the university does not require students' good command in English and Arabic. For example, in terms of Arabic competence, it is hard for students coming from senior high school since they did not learn it formally in their previous school. On the other hand, to master English is a big challenge for students graduating from traditional pesantren. For some students, they could master both international languages and many of them could not master both.

Besides, based on the interview with some students, learning Arabic is also not easy since they are not familiar with the vocabulary. They are also have difficulty in arranging sentences. They have low command in their Arabic proficiency and also use the traditional method in learning Arabic. This is confirmed by several studies conducted by (Ahmad, 1997; (Rahim, 2003; Aziz, Abdullah, \& Liau, 2005; Abdullah, 2006; Ghani \& Rahimi, 2005; Mohamad, 2007; Pa, 2008; Shukri, 2009; Ismail, et al. 2011; Ismail, 2011; Samah, 2012; Hanan, 2011). Their findings explained that most students prefer to just sit and listen to the teacher in learning the Arabic language. Moreover, they feel afraid to speak and be involved in activities in the Arabic Language class. As a result, (Razman, 2004) found that students face difficulties in understanding the Arabic Language subject.

(Hasan, 2000) states that the difficulty faced by many students of English as a foreign language is the lack of understanding of English pronunciation expressed at normal speed through listening material. On reading skills, (Rahmawati, 2011) argues that the problem faced for understanding reading texts lies in the lack of knowledge about reading material and ignorance of how to connect ideas between sentences with one another. W riting skills are difficult because these activities require a complex and systematic thought process, but need to be mastered by English students. According to (Rukmini, 2011), in communication writing skills are also important to master. The benefits will be felt when the written language is published and read by many people. So that the quality of writing must always be improved. For speaking skills, (Megawati, 2016) in her research found that the difficulty that students often face when speaking English lies in the lack of English vocabulary.

This also applies to students who are not from the English department. Each student certainly has an interest in a different field of science. So that not all like English and choose an English major. This cannot be separated from the problems that will arise when the learning process takes place (Megawati, 2016). To fulfill their obligations as students at a university, they are required to take English courses and even have to pass the TOEFL test with a fairly high score. For students who do not have a strong background in language knowledge from elementary to high school, they will feel overwhelmed by this. So that as English learners who do not study science in their fields (ESP learners) have the potential to produce a variety of responses in the learning process (Zoumin, 2005).

2. Lectures

According to Abdul Kodir (2019) lecturers play a huge role in implementing International language communication in the university. In UIN Sunan Gunung Djati Bandung, lecturers have not fully supported this policy to support international language communication. Lecturers' competence in English and Arabic proficiency vary. Some of them have good command in both English and Arabic. On the other hand, some lecturers have minimum competency in both languages. Many lecturers are able to perform one of them. In line with this, the University has not set a standard for lecturers' competence in International language 
competence. This circumstance hinders the implementation of International language communication. According to (Muhyidin, 2019) it will be better for Islamic studies to be delivered by Arabic and for General knowledge to be delivered using English. In other words, non-Islamic Faculty should implement English as medium of instruction and Islamic based faculties run Arabic as their medium of instruction. There is still a long way to go to achieve this condition.

Modern language learning systems are ideally based on needs analysis (AK). AK is a procedure of gathering information about learning needs at a certain level of learning, namely to formulate learning objectives and content (Richards, 2001); (Gall, Gall, \& Borg, 2003). At the college level, AK focuses on mastering language skills in accordance with the field of study of learners. The various aspects mentioned above involve the role of lecturers and students.

Lecturers have the same role related to assumptions about language and language learning at the level of the approach (Cunningsworth, 1995; Richards \& Rodgers, 2014). The majority of the application methods depend entirely on the lecturer as a source of knowledge and direction, catalysts, consultants, mentors, and learning models and developers interactional patterns between lecturers and students. The teaching design system is strongly influenced by the way the lecturer treats students according to the application of the chosen learning method, by reflecting the express and implicit response to various questions concerning the contribution of students in the learning process. This can be seen from the types of activities carried out, controlling the level of success of learning, applying various patterns of student grouping, the level of influence of other student learning, and their role as processors, performers, initiators, and problem solvers. Based on the results, it is found that some of the lectures are still not qualified profesionally to teach foreign language.

\section{Learning Facilities}

According to (Muhyidin, 2019), language learning facilities in the university need to be improved. The university has provided Language centre, Ma'had Al-Jami'ah and Ma'had Lughawy. In terms of usage, Language centre caters $6^{\text {th }}$ semester students and they use it 2 hours daily. Ma'had Al-Jami'ah can cater 450 students and Ma'had Lughawy is designed to cater Arabic education student only. Given this situation, thousands students do not have access to language service. To cater the need of International language learning, UIN Sunan Gunung Djati should provide dormitory to cater first year students to be trained and empowered their English and Arabic competencies. This need should be fulfilled in the future since good environment helps language learners to master International language competencies.

There are several inhibiting factors to international language communication. The limited availability of books and teaching materials is one of the most important factors in the implementation of quality learning. Availability of computers and adequate internet access as a form of technology utilization is still limited. Moreover, the lack of language laboratory facilities that can support language learning activities is also one of the influential factors in the lack of effective language learning process.

This section has elaborated in depth the challenges faced by the university to achieve the implementation of international language use in the campus. The challenges have been spotted and the solution to each burden has been proposed to make sure the implementation of international language policy will achieve its goal.

\section{Method Used}

Another aspect to consider is language learning method. According to Muhidin (2019), there are also lecturers who still use old method where educators only use one method and the English learning model, even though educators are required to use more than one English 
learning method and model, this is the goal so that English learning in the classroom will be fun so that students become active, creative and innovative students.

Effective learning is learning that is able to bring students to achieve the expected learning goals or competencies. While efficient learning is a learning activity that takes place using relatively little time and resources. Learning needs to be created into an interesting event in order to be able to increase students' interest and motivation to learn, so that it can be identified the characteristics of activities that are learning outcomes according to Rita Richey (Ibrahim, 2011), namely: (a) Learning is an activity that produces changes in a person both actual and potential, (b) The change is new abilities possessed in a relatively long time, (c) Changes occur because of conscious effort.

How to implement a learning will have a big influence on the ability of students to educate themselves. Successful teachers are not just charismatic and persuasive material presenters. Furthermore, successful teachers are those who engage students in tasks that are full of cognitive and social content, and teach them how to do these tasks productively. While effective students are able to describe information, ideas, and wisdom from their teachers and use learning resources effectively (Joyce, Weil, \& Calhoun, 2009).

\section{Results Achieved from The Implementation of International Language Policies at UIN Sunan Gunung Djati Bandung}

This study found that International language policy implementation has been applied in several types namely: regular class, language centre, Ma'had Al-Jami'ah and Mahad Lughawy. To investigate the implementation of international language policy, this study investigate data from language centre concerning students' achievement in English and Arabic. Based on internal source taken from Lanugage Centre source, students' achievement in English and Arabic can be presented in the following table:

Table 1. Result of posttest English and Arabic for UIN Sunan Gunung Djati Bandung Students in year 2016

\begin{tabular}{llll}
\hline $\begin{array}{l}\text { TOAFL (Test of Arabic } \\
\text { as Foreign Language) }\end{array}$ & \multicolumn{3}{l}{$\begin{array}{l}\text { TOEFA (Test of English } \\
\text { For Academics) }\end{array}$} \\
\hline Total of test takers & $: 2437$ & Total of test takers & $: 2438$ \\
\hline Number of Male & $: 983$ & Number of male & $: 828$ \\
\hline Number of female & $: 1454$ & Number of Female & $: 1610$ \\
\hline Highest score & $: 460$ & Highest score & $: 614$ \\
\hline Lowest score & $: 257$ & Lowest score & $: 257$ \\
\hline Band 1(218 - 300) & $: 593$ & Band 1(218 - 300) & $: 396$ \\
\hline Band 2(301 - 400) & $: 1806$ & Band 2(301 - 400) & $: 879$ \\
\hline Band 3 (401-500) & $: 38$ & Band 3(401-500) & $: 1107$ \\
\hline Band 4 (501 - 618) & $: 0$ & Band 4(501 - 618) & $: 56$ \\
\hline Average Value & $: 287$ & Average Value & $: 347$ \\
\hline
\end{tabular}

Referring to table 1 , it can be seen that the average scores or mean for TOAFL of UIN Sunan Gunung Djati Bandung students is 287. This score falls into lower category or band 1, from 200 to 300 . On the other hand, for TOEFA, their mean or average score is 347 . This score falls into fair category. Since it belongs to band 2 from 301 to 400 . Given these result, it can be concluded that students' achievement for TOEFA is better than TOAFL in terms of their mean score. Several assumptions can be made in relation to this result. These assumptions required further study. One of them is students previous background. More and more students from SMA background enroll to UIN Sunan Gunung Djati Bandung and they do not have previous experience in Arabic learning. in addition, the university has opened several faculties which are closely related with English medium instruction for their textbook. 


\section{CONCLUSION}

Based on the analysis and findings from the results of our study, regarding the Implementation of Policy and Cultivation of International Languages in Higher Education, we can conclude that the implementation of international language policies and civilization in higher education aims to improve the knowledge, skills and skills of students in international languages, so that they become graduates who are qualified and have good language competencies to be able to compete locally and globally.

Improving the ability of students in international language is part of the objectives of UIN Sunan Gunun Djati Bandung, through three learning systems including; semester credit system, Ma'had Al-Jami'ah, and Ma'had Lughawy system. Implementation of international language policies and civilization of UIN Sunan Gunun Djati Bandung has produced results, through strengthening knowledge, fostering skills, raising the skills of students who have international language competence so that they are able to compete both locally and internationally.

Constraints in the implementation of policies and acculturation in international languages UIN Sunan Gunun Djati Bandung includes; lack of funding, difficulty in maintenance procedures, diversity of educational backgrounds, and availability of supporting facilities and infrastructure.

\section{BIBLIOGRAPHY}

Rahim, A., A. (2003). Strategi pembelajaran bahasa Arab di kalangan pelajar Melayu/Anida binti Abdul Rabim. University of Malaya.

Abdullah, N., H. (2006). Permasalahan dalam pembelajaran bagi pelajar diploma pengajian Islam (bahasa Arab) di KUIS dan cara mengatasinya. Prosiding Wacana Pengajian Islam, Siri, 5, 199-208.

Academic Team UIN Bandung. (2015). UIN Sunan Gunung Djati Bandung Academic Guidelines.

Amirudin, N. (2017). Problematika pembelajaran bahasa Arab. 1-12.

Andriani, A. (2015). Urgensi pembelajaran bahasa Arab dalam pendidikan Islam. Ta'allum: Jurnal Pendidikan Islam, 3(1), 39-56.

Aziz, A., Abdullah, N., \& Liau, L. S. (2005). Kajian tentang persepsi pelajar UiTM terbadap kepentingan bahasa ketiga.

Badruzzaman. (2019, March 12). Interview with Badruzzaman.

Cunningsworth, A. (1995). Choosing your coursebook. Heinemann Oxford.

Gall, M. D., Gall, J. P., \& Borg, W. R. (2003). Educational Research an Introduction, Seventh Editions. University of Oregon. United State of America.

Ghani, K. A., \& Rahimi, N. M. (2005). Menilai kebolehbacaan buku teks bahasa Arab tinggi: Ke arah meningkatkan kemahiran membaca pelajar. Prosiding Wacana Pendidikan Islam, 4. Retrieved from http://ejournal.ukm.my/gema/article/view/56

Hanan, M. (2011). Asbab khauf lada talabah jami'ah malaya fi kulliyyah islamiyyah fi muhadathah. Projek Ilmiah. Fakulti Pengajian Bahasa Utama. Nilai: Universiti Sains Islam Malaysia.

Hasan, A. S. (2000). Learners' perceptions of listening comprehension problems. Language Culture and Curriculum, 13(2), 137-153.

Hidayat, N. S. (2012). Problematika Pembelajaran Bahasa Arab. An-Nida', 37(1), 82-88.

Ibrahim, S. (2011). Belajar, Pengajaran dan Pembelajaran (Konsep dan Implementasi). Pontianak: Fahruna Babagia Pers, 3.

Ismail, N. A. (2011). Istiratijiyah tanmiyah muhadathah bi al-lughah Arabiyah lada talabah sanah ula fi jamiah ulum Islamiyah maliziyah li al-ami al-dirasi 2010/2011 (BA Thesis, Islamic Science University of Malaysia). Retrieved from http://bit.ly/2XMyCfz 
Ismail, Z., Tamuri, A. H., Yusoff, N. M. R. N., \& Mohd Ala-Uddin Othman. (2011). Teknik pengajaran kemahiran bertutur bahasa arab di SMKA di Malaysia. GEMA Online ${ }^{\circledR}$ Journal of Language Studies, 11(2). Retrieved from http://ejournals.ukm.my/ gema/article/view/57

Joyce, B., Weil, M., \& Calhoun, E. (2009). Models of Teaching: Model-model pengajaran. Yogyakarta: Pustaka Pelajar.

Kodir, A. (2019, March 15). Interview with Abdul Kodir.

Mahmud. (2019, March 10). Interview with the Rector of UIN Sunan Gunung Djati Bandung.

Megawati, F. (2016). Kesulitan mahasiswa dalam mencapai pembelajaran bahasa Inggris secara efektif. PED AGOGLA: Jurnal Pendidikan, 5(2), 147-156.

Mohamad, A. H. (2007). Masalah Komunikasi Bahasa Arab di Kalangan Pelajar Bacelor Bahasa Arab di IPTA Malaysia. Prosiding Seminar Penyelidikan Dalam Pengajian Islam Ke, 4.

Moleong, L. J. (2004). Metodologi Penelitian Kualitatif. Bandung: PT Remaja Rosdakarya..(2009). Metodologi Penelitian Kualitatif (Edisi Revisi).

Muhyidin, A. (2019, March 12). Interview with Asep Mubyidin.

Mustafa, I. (2019, March 12). Interview with Iraadin Mustafa.

Pa, M. T. (2008). Isu-isu pengajaran bahasa dan kesusasteraan Arab di institut pengajian tinggi. Prosiding Seminar Pengajaran Babasa Dan Kesusasteraan Arab Di Institut Pengajian Tinggi Malaysia-SEBAKA, 22-23.

Rahmawati, I. F. (2011). Improving Eighth Graders' Reading Comprehension through Autonomous Strategy. SKRIPSI Jurusan Sastra Inggris-Fakultas Sastra UM.

Riant, N. (2008). Kebijakan Pendidikan Yang Unggul. Yogyakarta: Pustaka Pelajar.

Richards, J. C. (2001). Curriculum development in language teaching. Ernst Klett Sprachen.

Richards, J. C., \& Rodgers, T. S. (2014). Approaches and methods in language teaching. Cambridge university press.

Rukmini, A. S. (2011). The implementation of teacher corrective feedback in teaching writing descriptive text to the second year students of smp $n 1$ tunjungan in 2010/2011 academic year. Univerversitas Muhammadiyah Surakarta.

Saepurrohman, A. (2019, March 12). Interview with Aep Saepurrobman.

Samah, R. (2012). Pembinaan Ayat Bahasa Arab Dalam Kalangan Lepasan Sekolah Menengah Agama. GEMA Online ${ }^{\circledR}$ Journal of Language Studies, 12(2).

Shukri, K. (2009). Penggunaan strategi pembelajaran bahasa Arab dalam kalangan pelajar sekolah menengah agama (Thesis $\mathrm{PhD}$, Universiti Kebangsaan Malaysia). Retrieved from https://seminarpnparab2014.files.wordpress.com/2014/06/linamalini-mat-nafi.pdf

Sinaga, F. (2010). Peranan bahasa Inggris dalam era globalisasi. Retrieved July 20, 2016, from htpp://kursusinggris.wordpress.com

Stanford, P. (2003). Multiple intelligence for every classroom. Intervention in School and Clinic, 39(2), 80-85. https://doi.org/10.1177/10534512030390020301

Syakirah Mohd Razman. (2004). Penggunaan Kamus dalam Pembelajaran BAK: Satu Tinjauan di Kalangan Pelajar Tingkatan Tiga di Empat Buah SMKA (Thesis Sarjana, Universiti Kebangsaan Malaysia). Retrieved from http://bit.ly/2XMyCfz

Tangkilisan, H. N. S. (2003). Kebijakan publik yang membumi: Konsep, strategi \& kasus. Kerjasama Lukman Offset \& Yayasan Pembaruan Administrasi Publik Indonesia.

Tarmizi, A. (1997). Ta'lim maharat kalam wa ta'allumuba: Dirasah fi madrasah thanawiah wataniah diniah (MA Thesis, Malaya University). Retrieved from http://bit.ly/2XMyCfz

Wahida, B. (2017). Problematika pembelajaran bahasa Arab. Jurnal Al-Astar, 7(1), 43-64.

Wahyudin, D. (2019, March 12). Interview with Dedih Wahyudin. 
Wardah, W. (2016). Pembelajaran bahasa inggris di perguruan tinggi islam dalam konteks esp(English for spesific purpose). Al-Hikmah, 10(2). https://doi.org/10.24260/alhikmah.v10i2.618

Zoumin, N. (2005). Approaches to the bottlenecks of interdisciplinary education of English majors-Starting from the problems of ESP in the education of English majors. Foreign Language World, 5(006). Retrieved from http://en.cnki.com.cn/ Article_en/CJFDTotal-WYJY200505006.htm 